\title{
V.K. Grodetskyy
}

Department of Surgery and Urology (Cheif - Prof. A.G.Iftodiy) Bukovinian State Medical University

\section{MORPHOLOGIC CHANGES IN DYNAMICS AFTER CATGUT SUTURE OF HEPATIC TRAUMATIC INJURY \\ МОРФОЛОГІЧНІ ЗМІНИ В ДИНАМІЦ ПІСЛЯ УШИВАННЯ КЕТГУТОМ ТРАВМАТИЧ- НОГО ПОШКОДЖЕННЯ ПЕЧІНКИ}

Резюме. Метою дослідження є визначення особливостей застосування кетгуту при ушиванні травматичних ушкоджень печінки. Робота виконана в експерименті на 45 дорослих собаках, середньою масою 6-12 кг. Встановлено, що застосування кетгуту з метою ушивання травматичних дефектів печінки $є$ необгрунтованим та недоцільним, сприяє розвитку гнійних ускладнень травми, не забезпечує адекватні умови для загоєння рани печінки.

Ключові слова: травма печінки, ушивання, кетгут.

In the overall structure of acute injuries of the abdominal cavity traumatic liver damage has up to $8,2-$ $21,8 \%$ and is accompanied, depending on the severity of injury, by the mortality rate up to $80 \%[1,2]$. The frequency of septic complications after suture injury of the liver in recent years has no sustained downward trend.

In the structure of postoperative complications, about $30 \%$ of cases are festering complications of inflammatory nature associated with suture material. The presence of microbial factors in the area of liver increases inflammatory response of the liver tissue, leading to deterioration of reparative processes [1, 3-5]. In view of the mentioned above, there is an important question of suture material choice and its impact on regeneration of the set of traumatic injuries due to liver trauma. The majority of clinicians and researchers believe catgut is a classic material for correction of liver injury [6]. That is why it is considered to be appropriate to examine histopathological changes in the liver catgut sutures.

Objective: to identify the characteristics of histopathological picture and justification for the use of catgut in suturing traumatic liver injuries.

Material and methods. In accordance with scientific and methodological peculiarities and deontological constraints, the work is performed in experiment. The objects of the study were 45 adult dogs with an average weight $6.12 \mathrm{~kg}$. Ethically the experiment complies with the Order of the Ministry of Health of Ukraine №281 and other legal regulations in Ukraine.

Under pentothal sodium anesthesia after upper median laparotomy the right hepatic lobe was dissected with wound length of $0.9 \mathrm{~cm}$ and the depth of 0.5 $\mathrm{cm}$, followed by overlay knotted catgut sutures.
For histopathological studies, liver slices were taken during 2, 4, 6, 8 and 10 days of the experiment. Then slices were subjected to fixation in neutral $10 \%$ formalin solution, dehydration in ascending battery of spirits, and paraffinization. Sledging microtome was used for final slicing of 5-6 micrometers thickness. Histological slices were stained with hematoxylin and eosin. To assess the fibrous components they were stained according to Van Gieson technique, and then observed under light optic microscope at different magnifications.

Results and discussion. Two days after liver wounds suturing histological examination revealed that liver damage around the suture line was marked with hyperemia and swelling of the vascular walls. The focus of hemorrhage was surrounded by polymorphonuclear leukocytes area in which hemolyzed erythrocytes, fibrin threads were present. Perifocally there was discomplexing of hepatic structural elements, contours of hepatocytes cytoplasm and nuclei were poorly differentiated (alterative changes). In remote areas, there were signs of uneven blood vessels supply, swelling of hepatocytes, instability of lobe pattern.

4 days after following experimental traumatic catgut stitching of liver damage - dilated vessels and uneven blood supply were found. The endothelium was swollen. Around some vessels marked leukocytic infiltration was seen. Around suture material a narrow area of fibrin surrounded by massive leukocyte infiltrates and hemorrhages with hemolyzed erythrocytes and hemosiderin deposition was observed. On the periphery of hemorrhage, proliferating capillaries, damaged leukocytes were surrounded with cell detritus. In hepatocytes expressed granular and fatty degeneration, focal necrotic changes were found. Hepatic structural elements were (C) Grodetskyy V.K.., 2013 


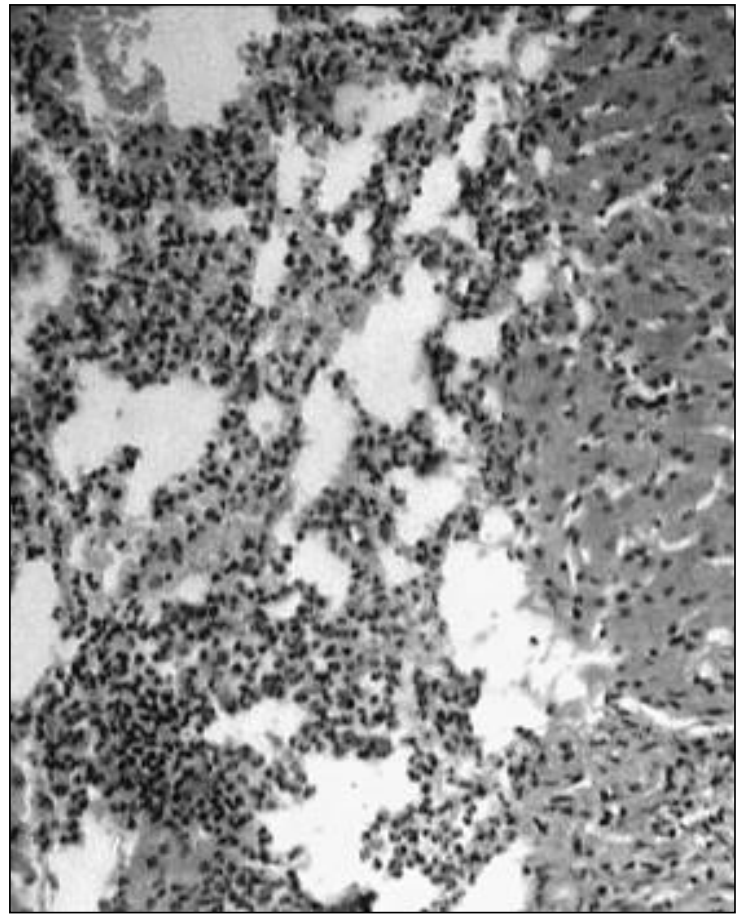

Fig. 1. Traumatic injury of the liver parenchyma in experiment. Application of catgut as suture material: hepatocytes around the damage area, microabscesses, hemorrhage, granulation tissue fragment island. Dog №18, female, $8 \mathrm{~kg}$ mass.

Hematoxylin and eosin staining. Magn. $\times 120$.

Fig. 2. Traumatic injury of the liver parenchyma in

discomplexing. The bile duct walls were penetrated by polymorphonuclear leukocytes, the duct epithelium was partially desquamated.

In dynamics, 6 days after the experiment hemorrhage was observed, sometimes in the form of small hematomas with hemolyzed red blood cells. These areas contain damaged neutrophils with moderate admixture of plasmatic cells and eosinophils. There was a proliferation of capillaries. Around the suture material pronounced leukocytic infiltration, proliferation of capillaries with swollen walls and proliferation of fibroblasts were seen. The walls of the bile ducts were penetrated by polymorphonuclear leukocytes, the duct epithelium was swollen with focal desquamations.

8 days after the experimental liver wounds suturing, around the suture material a marked infiltration by polymorphonuclear partially destroyed leukocytes, proliferation of capillaries, surrounded by leukocytes, sometimes with marked hemorrhage on the periphery were observed. Some degenerative and necrotic changes in the focal hepatocytes occurred. Pronounced leukocytic infiltration in the walls of the

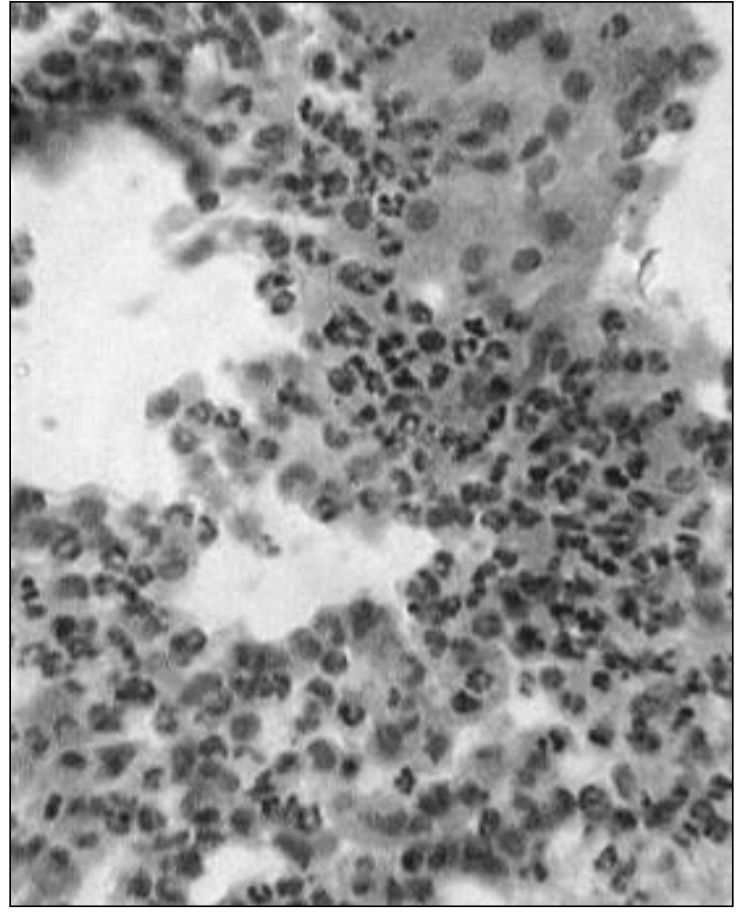

experiment. Application of catgut as suture material, fragment of microabscess at high magnification: hepatocytes' cellular conglomerate, neutrophilic granulocytes.

Dog №43, male, $6 \mathrm{~kg}$ mass.

Hematoxylin and eosin staining. Magn. $\times 120$.

bile ducts was seen.

10 days after using the same experimental conditions of liver damage, loci of the former damage were characterized by marked infiltration of the liver tissue by neutrophils, signs of suppurative cholangitis and perycholangitis with numerous hemorrhages containing hemosiderin, sometimes small abscesses (Fig. 1-2). The hepatocytes around the regeneration area had the signs of granular and hydropic degeneration or necrosis. Strands of catgut in histological preparations were not observed, they completely lysed during this period. Catgut was assumed to be dissolved by neutrophilic enzymes.

Conclusion. The use of catgut suture for the treatment of liver traumatic defects is unreasonable and impractical, as it promotes the development of purulent complications of trauma, does not provide adequate conditions for healing.

The prospect for further research is to examine in a comparative perspective, the characteristics of post-traumatic liver' wound healing with the use of other types of suture material.

\section{References}

1. Гродецький В.К. Обтрунтування вибору оптимального шовного матеріалу при травматичних пошкодженнях печінки / В.К. Гродеџький, А.Г. Іфтодій // Клінічна анатомія та оперативна хірургія. - 
2005. - T. 4, № 2. - С. 46-49. 2. Хірургія печінки та жовчовивідних шляхів / О.О. Шалімов, С.О. Шалімов, М.Ю. Ничитайло, Б.В. Доманський- К.: Здоров'я, 1993. - 512 c. 3. Blaker J.J. Development and characterization of silver-doped bioactive glass-coated sutures for tissue engineering and wound healing applications / J.J. Blaker, S.N. Nazhat, A.R. Boccaccini // Biomaterials. - 2004. - Vol. 25. № 7-8. - P. 13191329. 4. Bioactivity of degradable polymer sutures coated with bioactive glass / O. Bretcanu, E. Verne, L. Borello, A.R. Boccaccini // J. Mater. Sci. Mater. Med. - 2004. - Vol. 15, № 8. - P. 893-899. 5. Physical, biological and handling characteristics of surgical suture material: a comparison of four different multifilament absorbable sutures / E.S. Debus, D. Geiger, M. Sailer [et al.] // Eur. Surg. Res. - 1997. - Vol. 29 , № 1. - P. 52-61. 6. In vitro degradation and subsequent biomechanical changes of poly[lactide-co-glycolide] scaffolds prepared by mild heating under high pressure / B. Yu, C.J. Gao, D.P. Quan, Z.J. Lu // Di Yi Jun Yi Da Хие Хие Bao. - 2003. - Vol. 23, № 5. - P. 416-420.

\section{МОРФОЛОГИЧЕСКИЕ ИЗМЕНЕНИЯ В ДИ- НАМИКЕ ПОСЛЕ УШИВАННЯ КЕТГУТОМ ТРАВМАТИЧЕСКОГО ПОВРЕЖДЕНИЯ ПЕ- ЧЕНИ}

Резюме. Целью исследования является определение особенностей использования кетгута при сшивании травматических повреждений печени. Работа выполнена в эксперименте на 45 взрослых собаках, средней массой 6-12 кг. Установлено, что использование кетгута с целью ушивання травматических дефектов печени является необоснованным и нецелесообразным, способствует развитию гнойных осложнений травмы, не обеспечивает адекватные условия для заживления раны печени.

Ключевые слова: травма печени, ушивание, кетгут.

\section{MORPHOLOGIC CHANGES IN DYNAMICS AFTER CATGUT SUTURE OF HEPATIC TRAUMATIC INJURY}

Abstract. The aim of the study is to determine the catgut suture peculiarities in suturing liver injuries. The study is performed experimentally on 45 mature dogs. The use of catgut to suture traumatic defects on the liver is found to be unreasonable, provoking the development of suppurative complications of the injury, and does not promote adequate conditions to heal the wound.

Key words: liver injury, suture, catgut.

Bukovinian State Medical University (Chernivtsi)

Надійшла 07.10.2013 p. Рецензент - проф. Костюк Г.Я. (Вінниця) 